\title{
Daya Terima dan Uji Kekenyangan pada Bakso yang disubtitusi Jantung Pisang dan Modified Cassava Flour (Mocaf)
}

\section{Acceptance and Satiety Test of Meatball Subtituted Banana Blossom and Modified Cassava Flour (Mocaf)}

\author{
Siti Mei Saroh*, Luki Mundiastuti ${ }^{1}$
}

\begin{abstract}
ABSTRAK
Latar Belakang: Salah satu upaya untuk menurunkan prevalensi obesitas adalah dengan peningkatan konsumsi serat pangan yang dapat meningkatkan kekenyangan dan mencegah konsumsi kalori berlebih. Subtitusi jantung pisang dan tepung mocaf yang kaya serat pada bakso yang digemari masyarakat, diharapkan bisa menjadi alternatif makanan yang sehat dan kaya serat untuk mengurangi prevalensi obesitas.

Tujuan: Mengetahui daya terima, dan uji kekenyangan terhadap produk bakso Jantung Pisang dan tepung mocaf

Metode: Penelitian tahap pertama menggunakan rancangan percobaan faktorial menyilang, 3 formula terbaik dipilih dari 7 formula oleh 3 panelis terlatih, selanjutnya 3 formula terbaik dipilih oleh 25 panelis tidak terlatih. Pada tahap uji satiety menggunakan desain cross-over trial. Subjek adalah mahasiswa Universitas Airlangga, umur 12-25 tahun, IMT antara $18,5-28 \mathrm{~kg} / \mathrm{m} 2$. Penelitian cross-over trial dilakukan pada 14 subjek yang sehat yang memenuhi kriteria. Masing-masing $200 \mathrm{~g}$ Bakso biasa (FO) dan bakso modifikasi diberikan saat waktu sarapan pada hari yang berbeda. Penilaian hunger dan satiety diambil dengan kuisioner Visual Analog Scale (VAS).

Hasil: Formula terbaik adalah F3 ditinjau dari daya terima dan kandungan serat. Tidak ada perbedaan yang signifikan dalam rasa lapar setelah makan $(p=0,122)$ pada kedua makanan uji. Tidak terdapat perbedaan signifikan rasa kenyang setelah makan $(p=0,080)$.

Kesimpulan : Tidak ada perbedaan yang signifikan untuk rasa lapar dan rasa kenyang antara Bakso F3 yang disubtitusi $20 \%$ jantung pisang dan tepung $10 \%$ tepung mocaf dengan bakso kontrol. Hal ini terkait kandungan serat pada bakso modifikasi (F3) yang tidak cukup untuk memberikan efek kekenyangan.
\end{abstract}

Kata kunci: bakso, uji kekenyangan, jantung pisang, serat pangan, tepung mocaf 


\section{ABSTRACT}

Background: One of the efforts to reduce the prevalence of obesity is by increasing the consumption of dietary fiber. Dietary fiber can reduce weight, because it can enhance satiety and prevent excessive calorie consumption. Banana and Modified Cassava Flour (mocaf) are source of fiber. The substitution of banana blossom and mocaf in the meatball-one of favorite food is expected to be one of alternative solution of a healthy and fiber-rich food to reduce the prevalence of obesity. Objective: The purpose of this research was to determine the acceptability, and Satiety study of banana blossom and mocaf meatball .

Methods: The first stage of the study using a factorial crossed design, 3 best formulas were selected from 7 formulas by 3 professional panelists, then the best 3 formulas were selected by 25 untrained panelists. At the satiety test stage using a cross-over trial design. Subjects were students Universitas Airlangga Students, age criteria $12-25$ years, BMI $18.5-28 \mathrm{~kg}$.

Results: The best formula was $\mathrm{F} 3$ in terms of acceptance value and dietary fiber content. There was no significant difference in hunger after meal $(p=0.122)$ on both test foods. There was no significant difference in satiety feeling after meals ( $p=0.080)$.

Conclusion: There was no significant difference for hunger and satiety between the F3 meatballs substituted with $20 \%$ banana blossom and $10 \%$ mocaf with control meatballs. This is due to insufficient fiber content to give a satiety effect.

Keywords: meatballs, satiety study, banana blossom, dietary fiber, modified cassava flour

\footnotetext{
*Koresponden:

siti.mei-13@fkm.unair.ac.id

${ }^{1}$ Akademi Gizi Surabaya
}

\section{PENDAHULUAN}

Overweight dan obesitas dapat menjadi faktor resiko berbagai penyakit tertentu seperti diabetes tipe 2, jantung koroner, hipertensi dan berbagai macam kanker $^{1}$. Hampir 2 miliar orang dewasa di dunia mengalami kelebihan berat badan dan lebih dari setengah miliar mengalami obesitas $^{2}$. Salah satu pendekatan yang dapat dilakukan adalah membuat formulasi makanan yang rendah kalori dan dapat memberikan rasa kenyang atau satiety yang lebih baik sehingga dapat mengontrol asupan makan yang berlebih ${ }^{3}$. Satiety bisa diartikan dengan perasaan kenyang atau perasaan yang dapat menghalangi munculnya sensasi lapar setelah makan ${ }^{4}$. Ada berbagai cara untuk mengukur satiety salah satunya adalah Satiety index yang dikembangkan oleh Sussana Holt (1995), sebuah sistem yang mengukur kemampuan makanan yang berbeda-beda untuk memberikan rasa kenyang dengan roti tawar putih sebagai baseline ${ }^{5}$. Sedangkan cara yang lain adalah dengan mengukur tingkat kekenyangan (satiety) menggunakan subject appetite rating scale seperti Visual Analog Scale (VAS) yang membandingkan dua makanan uji dalam pengaruhnya terhadap tingkat kekenyangan ${ }^{6}$.

Uji epidemiologi dan uji klinis menunjukkan bahwa asupan serat pangan berbanding terbalik dengan kejadian obesitas, diabetes tipe dua, kanker dan penyakit kardiovaskuler ${ }^{7}$. Serat pangan mempunyai peran dalam penurunan berat badan melalui berbagai mekanisme. Makanan yang mengandung serat memiliki kalori yang rendah karena serat pangan hanya mengandung 1.5-2.5 $\mathrm{g}^{8}$. Berdasarkan kelarutannya serat pangan terbagi menjadi dua yaitu serat pangan yang terlarut dan tidak terlarut ${ }^{9}$. Serat tidak terlarut terdiri dari komponen polisakarida yang terdapat pada dinding sel, yaitu selulosa, lignin, dan hemiselulosa yang biasanya terdapat pada gandum, kacang-kacangan, beberapa produk padi-padian dan sayuran ${ }^{10}$. Serat tidak terlarut 
membantu melancarkan pencernaan dengan memberikan masa pada feses sehingga mempermudah pergerakan feses untuk menuju ke usus besar ${ }^{11}$. Serat pangan dicerna secara lambat oleh bakteri flora usus sehingga dapat mengatasi konstipasi ${ }^{12}$. Sedangkan serat terlarut terdiri dari nonsellulosa polisakarida seperti pektin, gum dan agar agar yang dapat ditemukan di buah-buahan, sayursayuran seperti jantung pisang, dan juga pada kacang-kacangan berperan untuk menunda pengosongan lambung, melambatkan absorbsi glukosa, dan menurunkan kadar kolestrol ${ }^{13}$. Sayur- sayuran seperti jantung pisang mengandung baik serat pangan terlarut dan serat pangan tidak terlarut ${ }^{14}$.

Pembuatan pangan fungsional yang dapat mencegah terjadinya obesitas sangat diperlukan. Pangan fungsional adalah pangan yang bisa bermanfaat bagi tubuh karena kandungan komponen zat aktifnya. Serat pangan adalah salah satu zat aktif pada pangan fungsional ${ }^{15}$. Pengembangan pangan fungsional yang tinggi serat dapat diterapkan pada makanan yang digemari oleh masyarakat. Bakso merupakan salah satu makanan cepat saji yang digemari seluruh kalangan. Bakso pada umumnya mengandung energi sebesar 190 kilokalori, protein 10,3 gram, karbohidrat 23,1 gram, lemak 6,3 gram, dan 0 gram serat pangan ${ }^{16}$. Penambahan serat pangan pada makanan favorit masyarakat diharapkan dapat meningkatkan asupan serat yang bermanfaat untuk mencegah obesitas.

Pisang merupakan salah satu komoditas unggulan di Indonesia. Pada tahun 2015 luas panen pisang mencapai 94 ribu ha ${ }^{17}$.Pisang dapat dimanfaatkan dengan luas tidak terkecuali dengan jantung pisang. Menurut riset jantung pisang mengandung energi sebesar $51 \mathrm{Kkal}$, protein 1,6 g, lemak $0.6 \mathrm{~g}$, karbohidrat total 9,9 g, serat pangan 5,7 $\mathrm{g}^{18}$. Sayangnya, konsumsi masyarakat terhadap masyarakat sangat kurang, karena pengolahan dan penyajian jantung pisang yang tidak praktis. Pengembangan produk yang siap saji dari jantung pisang seperti bakso, akan sangat bermanfaat untuk masyarakat untuk meningkatkan konsumsi serat pangan. Kebutuhan serat pangan harian adalah sebesar $25 \mathrm{~g}$ dengan kebutuhan energi sebanyak 2000 kalori. Namun, kebutuhan serat pangan dapat berubah sesuai dengan kebutuhan kalori ${ }^{19}$. Berdasarkan penelitian,konsumsi serat pangan sebanyak 14 $\mathrm{g} /$ hari dapat membantu untuk menurunkan asupan energy sebanyak $10 \%$ dan penurunan berat badan lebih dari $1,9 \mathrm{~kg}^{19}$. Subtitusi tepung dari Modified Cassava Flour (MOCAF) diharapkan dapat meningkatkan kandungan gizi pada produk sekaligus meningkatkan nilai ekonomis pada produk lokal ${ }^{20}$. Modified Cassava Flour adalah tepung yang berasal dari singkong yang difermentasi, sehingga memiliki kandungan serat yang lebih tinggi dibandingkan dengan tepung terigu dan tepung tapioka biasa ${ }^{21}$. Tepung Mocaf mengandung serat sebesar $2,5 \mathrm{~g} / 100 \mathrm{~g}^{20}$. Sayangnya tepung mocaf juga belum banyak dikenal dan digunakan oleh masyarakat.

Penelitian ini bertujuan untuk mengetahui daya terima, dan uji kekenyangan pada produk bakso jantung pisang dan tepung mocaf. Produk yang dihasilkan diharapkan dapat menjadi pilihan makanan sehat untuk masyarakat dalam rangka mencegah kelebihan berat badan.

\section{METODE}

Penelitian ini menggunakan metode eksperimental murni. Penelitian tahap pertama menggunakan rancangan percobaan faktorial menyilang. Faktor pertama adalah subtitusi ayam dengan jantung pisang, dan faktor kedua adalah subtitusi tepung tapioka dengan tepung mocaf. Proporsi jantung pisang dan tepung mocaf dapat dilihat pada tabel 1 . Bahan utama yang digunakan adalah Ayam, daging sapi, jantung pisang kepok, tepung tapioka, tepung sagu, tepung maizena dan tepung Mocaf merek Ladang Lima. Pembuatan bakso diawali dengan menakar bahan - bahan lalu dihaluskan dan dicampur merata. Jantung pisang terlebih dulu dipotong potong dan direndam dalam larutan jeruk nipis untuk mencegah oksidasi, serta ditambahkan garam untuk menghilangkan rasa sepat ${ }^{22}$. Jantung pisang kemudian direbus, dihaluskan dan dicampur dengan bahan lainnya. Adonan dicetak bulat dan direbus selama 12 menit hingga mengapung. Bakso didinginkan di wadah yang bersih dan 
dikemas dalam plastik untuk penyajian. Formula bakso terbaik yang didapatkan dari hasil penelitian terhadap daya terima panelis terhadap bakso dari rata-rata skor tertinggi dan berdasarkan kandungan gizi berdasarkan software nutrisurvey.

Tabel 1. Karakterisik Formulasi Bakso Jantung Pisang

\begin{tabular}{|c|c|c|c|c|}
\hline Karakteristik & Fo & F1 & F3 & F5 \\
\hline \multicolumn{5}{|l|}{ Bahan } \\
\hline $\begin{array}{l}\text { Daging } \\
\text { Ayam (gr) }\end{array}$ & 150 & 135 & 120 & 105 \\
\hline $\begin{array}{l}\text { Jantung } \\
\text { Pisang (gr) }\end{array}$ & 0 & 15 & 30 & 45 \\
\hline $\begin{array}{l}\text { Daging sapi } \\
\text { (gr) } \\
\text { Tepung }\end{array}$ & 50 & 50 & 50 & 50 \\
\hline $\begin{array}{l}\text { Tapioka } \\
\text { (gr) }\end{array}$ & 60 & 51 & 51 & 51 \\
\hline $\begin{array}{l}\text { Tepung } \\
\text { mocaf (gr) }\end{array}$ & 0 & 9 & 9 & 9 \\
\hline $\begin{array}{l}\text { Tepung } \\
\text { Sagu (gr) }\end{array}$ & 20 & 20 & 20 & 20 \\
\hline \multicolumn{5}{|l|}{ Tepung } \\
\hline $\begin{array}{l}\text { Maizena } \\
\text { (gr) }\end{array}$ & 20 & 20 & 20 & 20 \\
\hline Total (gr) & 300 & 300 & 300 & 300 \\
\hline $\begin{array}{l}\text { Kandungan gi } \\
\text { Kandungan } \\
\text { kalori/ }\end{array}$ & & & & \\
\hline $\begin{array}{l}100 \mathrm{~g} \\
\text { Kandungan }\end{array}$ & 183,7 & 181,7 & 178,9 & 176,42 \\
\hline $\begin{array}{l}\text { Serat / } \\
100 \mathrm{~g}\end{array}$ & 0,4 & 1,4 & 1,6 & \\
\hline $\begin{array}{l}\text { Protein/ } \\
\text { per } 100 \mathrm{~g}\end{array}$ & 15,2 & 14,4 & 13,3 & 12,2 \\
\hline
\end{tabular}

Alat yang digunakan adalah timbangan, sendok, mangkuk, pisau, food processor, dan panci. Alat penelitian untuk proses pembuatan bakso adalah blender, pisau, talenan, lemper atau cobek, panci perebus, mangkuk, kompor, timbangan meja, mangkuk saji, tusuk gigi dan kuisioner organoleptik hedonik dan kuisioner Visual Analog Scale (VAS) yang dikembangkan oleh Karalus (2011) dengan skala pengukuran $0-15 \mathrm{~cm}^{23}$.

Parameter yang diamati dalam uji organoleptik adalah rasa, tekstur, kekenyalan dan warna pada bakso. Penelitian pendahuluan dilakukan pada 3 panelis terbatas yaitu, Dosen Gizi Fakultas Kesehatan Masyarakat Universitas Airlangga dan 25 mahasiswi dan mahasiswa Fakultas Kesehatan Masyarakat Universitas Airlangga sebagai panelit tak terlatih. Tujuh formula yang terdiri dari 6 formula perlakuan dan 1 formula kontrol diujikan untuk mendapatkan 3 formula terbaik. Tiga formula terbaik yaitu F1, F3, F5 diujikan kepada panelis tak terlatih untuk mendapatkan formula yang terbaik ${ }^{23}$.

Penelitian tahap selanjutnya menggunakan desain cross-over trial. Subjek adalah mahasiswa dan mahasiswi Universitas Airlangga yang dalam keadaan sehat. Subjek dipilih berdasarkan kriteria umur 17-25 tahun,BMI antara $18,5-28 \mathrm{~kg} / \mathrm{m} 2$. Masingmasing $200 \mathrm{~g}$ bakso kontrol dan bakso modifikasi yang paling disukai panelis diberikan pada subjek dengan protokol uji cross-over. Subjek mengikuti uji satiety pada pukul 8 pagi. Sebelumnya responden diminta untuk tidak konsumsi apapun kecuali air putih dari pukul 10 malam. Setiap subjek mengkonsumsi bakso kontrol dan bakso modifikasi pada kesempatan yang berbeda dengan jarak 4 hari. Uji satiety diambil dengan kuisioner Visual Analog Scale (VAS) yang terdiri dari pertanyaan tentang rasa lapar dan rasa kenyang. Penelitian ini telah disetujui oleh komisi etik Fakultas Kesehatan Masyarakat Universitas Airlangga dengan no 295-KEPK.

Data yang diperoleh dari kuisioner organoleptik dianalisis dengan uji friedman untuk melihat nilai mean rank. Uji kekenyangan bakso biasa (FO) dan 1 bakso modifikasi yang terbaik, data yang diperoleh dari kuisioner VAS dianalisis dengan Paired Sample T-test jika data terdistribusi normal, jika tidak maka mengguanakan uji Wilcoxcon. Analisis statistik menggunakan SPSS 2.01 untuk windows 2007.

\section{HASIL DAN PEMBAHASAN}

\section{Daya Terima}

Hasil uji organoleptik secara keseluruhan dapat dilihat pada Tabel 2 nilai mean rank tertinggi terdapat pada FO $(2,68)$ dan F3 $(2,76)$ dan nilai terendah ada pada F5 
$(2,20)$. Bakso F3 lebih disukai dibandingkan dengan bakso formula lain karena memiliki warna abu abu sedang khas bakso daging. Bakso F1 kurang disukai karena warnanya pucat, sedangkan bakso F5 kurang disukai karena memiliki warna terlalu gelap. Hal ini sebagai akibat dari reaksi pencoklatan atau browning reaction dari jantung pisang saat pemotongan dan pemasakan ${ }^{24}$. Semakin banyak proporsi jantung pisang, maka bakso berwarna semakin gelap. Penelitian yang dilakukan pada pembuatan biskuit yang ditambahkan jantung pisang, menunjukkan bahwa kandungan jantung pisang yang semakin banyak membuat biskuit semakin berwarna coklat ${ }^{25}$.

Aroma merupakan sifat visual yang dapat digunakan untuk menilai kualitas dengan uji organoleptik menggunakan indera sensorik penciuman yang sensitif ${ }^{26}$. Dari tabel 2 memperlihatkan bahwa aroma bakso yang mendapatkan penilaian paling tinggi adalah pada fomula F0 dengan nilai mean rank 2,88, lalu F1 memiliki nilai mean rank 2,54. Berdasarkan tingkat kesukaan warna, penilaian F5 merupakan penilaian terendah dengan nilai mean rank 2,12. Tidak ada aroma khas jantung pisang yang terlalu menganggu, sehingga aroma bakso dapat diterima oleh panelis. Hal ini sejalan dengan hasil penelitian mengenai pengaruh jantung pisang terhadap chiffon, yang mana jantung pisang tidak mempengaruhi aroma chiffon cake $^{27}$. F0 dan F1 memiliki proporsi daging ayam paling banyak sehingga paling disukai oleh panelis.
Berdasarkan tabel 2 nilai mean rank tertinggi rasa bakso terdapat pada bakso F1 $(2,85)$ dan F3 $(2,44)$. Tidak terdapat rasa yang aneh dan dominan yang disebabkan oleh jantung pisang dalam ketiga formula bakso. Hal ini berkaitan dengan pemilihan jantung pisang kepok yang tidak memiliki rasa sepat saat diolah ${ }^{28}$. Namun, semakin banyak proporsi jantung pisang, proporsi daging ayam semakin menurun membuat nilai kesukaan terhadap rasa semakin juga menurun.

Berdasarkan tabel 2, nilai mean rank tertinggi terdapat pada bakso F0 $(2,88)$ dan bakso $\mathrm{F} 3(2,80)$ dan nilai terendah pada bakso F5 $(1,60)$. Bakso F5 memiliki nilai yang paling rendah karena bakso kurang kompak dan terlalu lembek. Jantung pisang memiliki serat yang mirip seperti daging. Daya terima dari ketiga formula bakso yang terpilih berdasarkan rata-rata keseluruhan formula bakso, panelis memilih formula bakso dengan nilai sebesar 3,54 yang berarti disukai panelis.

\section{Kandungan Serat Pangan}

Kandungan serat pangan dihitung dengan software nutrisurvey. Kandungan gizi untuk tepung mocaf didapatkan dari nutrition facts pada kemasan produk. Kandungan serat pangan jantung pisang jenis Musa paradisiaca atau pisang kepok diketahui berdasarkan penelitian sheng et. al jumlah total serat pangan (total dietary fiber) ditentukan dengan metode enzymatic gravimetric yang dikeluarkan oleh Association of Official Analytical Chemist (AOAC) ${ }^{29}$.

Tabel 2. Nilai Meank Rank Penilaian Organoleptik Panelis Tidak Terlatih Terhadap Bakso Jantung Pisang

\begin{tabular}{lccccccccc}
\hline \multirow{2}{*}{ Formula } & \multicolumn{2}{c}{ Warna } & \multicolumn{2}{c}{ Aroma } & \multicolumn{2}{c}{ Tekstur } & \multicolumn{2}{c}{ Rasa } & Total \\
\cline { 2 - 8 } & $\boldsymbol{M} \boldsymbol{R}$ & $\mathbf{R K}$ & $\boldsymbol{M R}$ & $\mathbf{R K}$ & $\boldsymbol{M R}$ & $\mathbf{R K}$ & $\boldsymbol{M R}$ & $\mathbf{R K}$ & Skor \\
\hline F0 & 2,68 & 4 & 2,88 & 4 & 2,88 & 4 & 2,85 & 4 & 16 \\
F1 & 2,36 & 2 & 2,54 & 3 & 2,72 & 2 & 2,35 & 2 & 9 \\
F3 & 2,76 & 3 & 2,46 & 2 & 2,80 & 3 & 2,44 & 3 & 11 \\
F5 & 2,20 & 1 & 2,12 & 1 & 1,60 & 1 & 2,35 & 1 & 4 \\
\hline
\end{tabular}

Keterangan : $M R=$ Mean Rank, RK=Rangking 
Tabel 3. Rasa Lapar (Hunger feeling) dan Rasa kenyang ( Satiety feeling) setelah konsumsi Bakso F0 dan Bakso F3

\begin{tabular}{lccc}
\hline \multicolumn{1}{c}{ Penilaian } & Bakso F0 & Bakso F3 & P \\
\hline Hunger Visual Analog Scale & & & \\
Baseline/menit (mm) & $54,4 \pm 8,2$ & $54,1 \pm 6,7$ & 0,78 \\
20 menit setelah makan & $12,8 \pm 2,0$ & $13,5 \pm 2,5$ & 0,122 \\
\hline Satiety Visual Analog Scale & & & \\
Baseline/menit (mm) & $6,9 \pm 2,0$ & $6,87 \pm 1,93$ & 0,879 \\
20 menit setelah makan & $49,0 \pm 6,0$ & $47,84 \pm 5,4$ & 0,080 \\
\hline
\end{tabular}

Keterangan: Data disajikan dalam bentuk mean \pm SD

Jumlah total kandungan gizi pada 3 formula dapat dilihat pada tabel 1. Kandungan serat pangan tertinggi yaitu pada F5 sebesar $2 \mathrm{~g}$ per $100 \mathrm{~g}$ bakso.

\section{Uji Kekenyangan}

Dari 14 subjek yang dipilih, 3 laki-laki dan 11 perempuan. Rata-rata umur responden adalah 20 tahun dengan rata-rata BMI 21,6 $\mathrm{kg} / \mathrm{m} 2$. Semua responden adalah mahasiswa Universitas Airlangga. Pada penelitian sebelumnya, formula terbaik, yaitu F3 dipilih berdasarkan nilai daya terima dan kandungan gizinya untuk dilakukan uji kekenyangan. Berdasarkan tabel 3 dapat dilihat bahwa tidak ada beda antara bakso F0 dan bakso F3 pada nilai rasa lapar dan rasa kenyang. Pada umumnya, serat pangan diketahui dapat meningkatkan rasa kenyang, yang mana berkaitan dengan sifatnya dalam menambah bulk atau muatan dan meningkatkan viskositas pada makanan ${ }^{9}$. Pada beberapa penelitian menunjukkan bahwa dosis dibawah 6,25 g kurang berpengaruh terhadap nilai rasa lapar dan kenyang ${ }^{30}$. Penelitian yang membandingkan susu kaya yang mengandung $3 \mathrm{~g}$ serat dengan makanan yang tidak mengandung serat,menunjukkan bahwa tidak ada perbedaan yang signifikan pada rasa kenyang atau satiety ${ }^{31}$.

Berbagai faktor dapat mempengaruhi rasa lapar dan kenyang. Makanan yang tinggi protein dan karbohidrat juga dapat mempengaruhi tingkat kekenyangan atau satiety. Makanan dapat memiliki efek yang optimal pada pengendalian nafsu makan ketika makanan tersebut tinggi protein, serat pangan dan rendah lemak. Berdasarkan penelitian mengenai pemberian makanan berprotein tinggi menghasilkan perbedaan yang signifikan dibandingkan dengan makanan yang rendah protein pada rasa kenyang dan lapar ${ }^{32}$. Pada tabel 1 menunjukkan bahwa kandungan protein pada bakso F0 15,2 g sedangkan F3 mengandung protein sebesar 13,2 g. Sehingga, kandungan protein pada bakso kontrol yang lebih besar dari bakso F3 dapat mempengaruhi rasa lapar dan rasa kenyang.

Kelebihan dari penelitian ini adalah karena penggunaan desain cross-over trial, sehingga pada uji kekenyangan hanya membutuhkan subjek yang sedikit. Pengaruh kovarian perancu berkurang karena setiap subjek berfungsi sebagai kontrolnya sendiri. Sedangkan penelitian ini memiliki keterbatasan yaitu tidak dilakukannya uji gula darah sebelum uji kekenyangan dilakukan.

\section{KESIMPULAN}

Berdasarkan uji organoleptik, Bakso F3 memiliki nilai meank rank tertinggi yaitu sebesar 3,54 (20\% jantung pisang, dan $15 \%$ tepung mocaf). Kandungan serat pangan F3 berdasarkan perhitungan software nutrisurvey adalah sebesar 1,6/100 g dan 3,2 per takaran saji (200 g). Tidak ada perbedaan yang signifikan antara perasaan lapar setelah mengkonsumsi bakso yang kaya serat dibandingkan dengan bakso biasa yang tidak mengandung serat. Namun bakso modifikasi bisa menjadi alternatif kudapan yang sehat, untuk meningkatkan asupan serat pangan. Perlu adanya penelitian selanjutnya untuk mengetahui jenis serat pangan pada jantung pisang dan tepung mocaf, serta efeknya terhadap rasa lapar, rasa kenyang dan penurunan asupan energi. 


\section{ACKNOWLEDGEMENT}

Penulis mengucapkan terima kasih kepada Dosen Gizi Fakultas Kesehatan Masyarakat, Universitas Airlangga selaku panelis terbatas dan Mahasiswa Universitas Airlangga selaku panelis tak terlatih dalam penelitian ini, serta teman-teman Rumah Belajar "Kardelen" yang membantu dalam pengambilan data.

\section{REFERENSI}

1. OECD Directorate for Employment. OBESITY Update. (2014).

2. WHO. Obesity. (2016). Available at: http://www.who.int/topics/obesity/en/ . (Accessed: 2nd January 2016)

3. van Kleef, E., van Trijp, J. C. M., van den Borne, J. J. G. C. \& Zondervan, C. Successful Development of Satiety Enhancing Food Products: Towards a Multidisciplinary Agenda of Research Challenges. Food Sci. Nutr. 52, 611-628 (2012).

4. Due, A., Karhunen, L., Saarela, M. \& Lyly, M. Satiety, weight management and foods. Health (San Francisco) 3, (2009).

5. Burton, P. \& Lightowler, H. J. Influence of bread volume on glycaemic response and satiety. Br. J. Nutr. 96, 877-882 (2006).

6. Karalus, M. B. The Creation and Testing of a Scale to Measure the Subjective Experiences of Hunger and Satiety $A$. (University of Minnesota, 2011).

7. Stewart, N. The health benefits of dietary fiber consumption of adults in the United States. (2014).

8. DeVries, J. W. Total dietary fiber. Medallion Lab. Anal. Prog. 11, 8 (2012).

9. Anderson, J. W. et al. Health benefits of dietary fiber. Nutr. Rev. 67, 188-205 (2009).

10. Burton-freeman, B., Liyanage, D., Rahman, S. \& Edirisinghe, I. Ratios of soluble and insoluble dietary fibers on satiety and energy intake in overweight pre- and postmenopausal women 1. 4, 157-168 (2017).
11. Lattimer, J. M. \& Haub, M. D. Effects of dietary fiber and its components on metabolic health. Nutrients 2, 12661289 (2010).

12. Slavin, J. \& Green, H. Dietary fibre and satiety. 32, 32-42 (2007).

13. DeVries, J. W. et al. The definition of dietary fiber. Cereal Foods World 46, 112-129 (2001).

14. Bhaskar, J. J., Chilkunda, N. D. \& Salimath, P. V. Banana ( Musa sp. var. elakki bale) Flower and Pseudostem: Dietary Fiber and Associated Antioxidant Capacity. (2012).

15. Adam, C. L. et al. Effects of Dietary Fibre (Pectin ) and / or Increased Protein ( Casein or Pea ) on Satiety, Body Weight , Adiposity and Caecal Fermentation in High Fat Diet-Induced Obese Rats. PLOS One 11, 1-16 (2016).

16. Firahmi, N. Sifat fisik dan organoleptik bakso yang dibuat dari daging sapi dengan lama pelayuan berbeda. Al Ulum Sains dan Teknol. 1, 39-45 (2000).

17. Pusat Data dan Sistem Informasi Pertanian. Outlook Komoditas Pertanian. (2016).

18. Sheng, Z. et al. Investigation of dietary fiber, protein, vitamin $E$ and other nutritional compounds of banana flower of two cultivars grown in China. 9, 3888-3895 (2010).

19. Slavin, J. L. Dietary fiber and body weight. Nutrition 21, 411-418 (2005).

20. Budiarto. Opportunity of modified cassava flour (mocaf) as wheat flour substitute an alternative materials to support food security. in Budiarto 837847 (2011).

21. Kurniati, L. I., Aida, N., Gunawan, S. \& Widjaja, T. Mocaf ( modified cassava flour ). J. Tek. Pomits 1, 1-6 (2012).

22. S, A. K. \& Scholar, M. T. Proximate Composition and Antioxidant Activity of Banana Blossom of Two Cultivars in India. 7, 13-22 (2016).

23. Saroh, S. M. Pengaruh Subtitusi Jantung Pisang Dan Modified Cassava Flour ( Mocaf) Terhadap Daya Terima Dan Tingkat Kekenyangan (Satiety) Bakso Kaya Serat. (Universitas Airlangga, 2018). 
24. Wickramarachchi, K. S. \& Ranamukhaarachchi, S. L. Preservation of Fiber-Rich Banana Blossom as a Dehydrated Vegetable. ScienceAsia 31, 265-271 (2005).

25. Puraikalan, Y. D. Development and Evaluation of Banana Blossom Incorporated Dark Chocolate. Int. J. Sci. Res. 4, 2013-2015 (2015).

26. Vindras, C. et al. Technical Tasting Guide: Tools to integrate organoleptic quality criteria in breeding programs. (Institut Techniwue de L'Agriculture Biologique, 2017).

27. Aprilia, P. Pengaruh Subtitusi Tepung Jantung Pisang Terhadap Kualitas Chiffon Cake. (Universitas Negeri Semarang, 2015).

28. Meiske, W. Kualitas Bakso Berbahan Dasar Daging Ayam dan Jantung Pisang dengan Bahan Pengikat Tepung Sagu. J. Apl. Teknol. Pangan 2, 36-39 (2011).
29. Sheng, Z. et al. Antioxidant properties of banana flower of two cultivars in China using 2 , 2-diphenyl-1-picrylhydrazyl ( DPPH ,) sulphonate ( ABTS ) and inhibition of lipid peroxidation assays. 10, 4470-4477 (2011).

30. Ibarra, A., Astbury, N. M., Olli, K., Alhoniemi, E. \& Tiihonen, K. Effect of Polydextrose on Subjective Feelings of Appetite during the Satiation and Satiety Periods: Nutrients 8, 1-19 (2016).

31. Chandra, D. N. \& Bardosono, S. The effect of fiber-rich milk and equicarbohydrate snack on glycemic and insulin response and satiety feeling. 8592 (2016).

32. Fathimah, F. Z. Pengaruh Pemberian Sarapan Tinggi Protein Terhadap Rasa Kenyang Wanita Obesitas. (Universitas Diponegoro, 2014). 